\title{
Palaeontologia Electronica
}

http://palaeo-electronica.org

\section{Reaffirming the Palaeontologia Electronica brand: A note on changes to publication priorities}

\author{
Andrew M. Bush, Julien Louys, Laura A.B. Wilson, \\ and Jennifer Pattison Rumford
}

\begin{abstract}
Palaeontologia Electronica was conceived as an online forum for the easy exchange of ideas and data among paleontologists (MacLeod and Patterson, 1998), and for 22 years we have been committed to disseminating technical and research articles in paleontology that will engender discussion within the community (Louys et al., 2017).

Until now, it has been our editorial policy to send the vast majority of submitted manuscripts out for review, irrespective of significance, subdiscipline, or length. However, within the last few years we have seen two parallel developments in paleontological scientific publishing that impact this policy. First, most paleontological journals now publish online, and an increasing number are online-only, with access to the same technologies that once made PE unique. Second, we have seen a year-on-year increase in the number of submissions to journals. In our case, some of the manuscripts we receive would traditionally have been published in region-specific journals, including descriptions of fossil finds of local importance or simple taxonomic treatments that, while fully deserving publication, are of less priority for an international journal like PE. Our resolution to keep PE completely free for all authors and readers has meant that our volunteer editors are struggling to keep up with the increasing volume of submissions. Thus, in order to move forward in a sustainable fashion and to reaffirm the principals under which we were founded, we will begin rejecting a greater proportion of manuscripts submitted to us prior to review. Without this change, we fear that the time it takes to process and publish manuscripts will rise beyond a reasonable level.
\end{abstract}

\footnotetext{
Andrew M. Bush. Department of Ecology and Evolutionary Biology and Center for Integrative Geosciences, University of Connecticut, 75 N. Eagleville Rd, Storrs, Connecticut 06269-3043 USA, andrew.bush@uconn.edu

Julien Louys. Australian Research Centre for Human Evolution, Environmental Futures Research Institute, Griffith University, Brisbane, Australia, j.louys@griffith.edu.au

Laura A.B. Wilson. School of Biological, Earth and Environmental Sciences, University of New South Wales, Sydney, NSW, 2052, Australia, laura.a.b.wilson@gmail.com

Jennifer Pattison Rumford. Palaeontologia Electronica, Texas, USA, jennifer.rumford@gmail.com
}

Keywords: Electronic publishing, palaeontology, open access, journal

Bush, Andrew M., Louys, Julien, Wilson, Laura A.B., and Rumford, Jennifer Pattison. 2019. Reaffirming the Palaeontologia Electronica brand: A note on changes to publication priorities. Palaeontologia Electronica 22.1.1E 1-2. https://doi.org/10.26879/191E palaeo-electronica.org/content/2019/2478-commentary-priorities

Copyright: March 2010 Coquina Press. This is an open access article distributed under the terms of the Creative Commons Attribution License, which permits unrestricted use, distribution, and reproduction in any medium, provided the original author and source are credited.

creativecommons.org/licenses/by/4.0/ 
Henceforth, PE will prioritize manuscripts that include one or more of the following:

1) Development or use of innovative paleontological methods, which may include imaging techniques, preparation techniques, statistical analyses, etc.

2) High-quality illustrations

3) Topic of broad interest, which may include the description of fossils of particular interest or exceptional preservation, analysis of paleobiological patterns and processes, or comprehensive treatments of a particular taxon or flora/ fauna

4) Unusual structure or media; subject matter that is directly relevant to paleontology but not typical of standard paleontology manuscripts

Manuscripts that do not meet these criteria may not be sent out for review - for example, manuscripts that seem appropriate for a more local or regional venue. PE has some capacity to publish manuscripts that are longer than the typical journal article (e.g., monographs), but please contact the editors before submission to discuss feasibility.

Palaeontologia Electronica has experienced tremendous growth in the past two decades (Louys et al., 2017a, figure 1), and we would like to thank all of our authors and readers for their continued support. PE is able to publish open-access articles without charging fees to authors because of the generous financial support of our institutional sponsors (the Paleontological Society, Palaeontological Association, Society of Vertebrate Paleontology, and Western Interior Paleontological Society) and individual patrons (Norman MacLeod, Catherine Badgley, Andrew A. Farke, Julien Louys, Michael Archer, and Ben Grace; see Louys et al., 2017b). Our publication model is also possible thanks to our volunteer editors, who do much of the work that paid staff perform at other journals.

\section{REFERENCES}

Louys, J., Bush, A., Hagadorn, J.W., MacLeod, N., Patterson, R.T., Polly, P.D., and Rumford, J.P. 2017a. Twenty years online! A brief history of Palaeontologia Electronica. Palaeontologia Electronica 20.1.1E:1-13. https://doi.org/10.26879/171E https://palaeo-electronica.org/content/2017/1843-twenty-years-online

Louys, J., Bush, A., and Rumford, J.P. 2017b. Palaeontologia Electronica needs your help! Palaeontologia Electronica 20.2.2E:1-2. https://doi.org/10.26879/172E https://palaeo-electronica.org/content/2017/1904-commentary-sponsorships-and-updates

MacLeod, N. and Patterson, R.T. 1998. The role and promise of electronic publishing in paleontology. Palaeontologia Electronica Editorial 1.1.

https://palaeo-electronica.org/content/the-role-and-the-promise-of-electronic-publishing-inpaleontology 